\title{
Gender dan Korupsi \\ (Pengaruh Kesetaraan Gender DPRD dalam Pemberantasan Korupsi di Kota Yogyakarta)
}

\author{
Aroma Elmina Martha \\ Dwi Hastuti \\ Fakultas Hukum Universitas Islam Indonesia. \\ Jl. Tamansiswa No 158 Yogyakarta \\ aroma@uii.ac.id
}

\begin{abstract}
Gender Gender and corruption are the recent problems in the anti-graft issue. This research is aimed at understanding the profile and gender equality influence in the corruption eradication attempts in DPRD Kota Yogyakarta. The research uses the combination method between quantitative and qualitative data. The result of the research shows that: First, the aspects of values, state governance ethics, attitude guidance and accountability of women are better than those of men. Women have nine indicators of excellence, while male members of the legislatives only have seven indicators of excellence. However, there is a gender inequality in DPRD Kota Yogyakarta. The large gap of inequality occurs in the control of and benefit for the women in each activity they follow. Second, the superiority of woman in the corruption eradication attempt will not be meaningful without gender equality.
\end{abstract}

Key words: Gender, corruption, DPRD, Yogyakarta City

\begin{abstract}
Abstrak
Gender dan korupsi merupakan masalah terbaru dalam isu anti korupsi. Penelitian ini bertujuan mengetahui profil dan pengaruh kesetaraan gender dalam upaya pemberantasan korupsi di DPRD Kota Yogyakarta. Pada penelitian ini menggunakan metode penggabungan antara data kuantitatif dan data kualitatif. Hasil penelitian menunjukkan bahwa: pertama, aspek nilai-nilai, aspek etika penyelenggaraan negara, aspek pedoman perilaku, dan aspek akuntabilitas perempuan lebih unggul dibanding laki-laki. Perempuan memiliki 9 indikator yang unggul. Sedangkan anggota dewan laki-laki memiliki 7 indikator yang lebih unggul. Namun, terdapat ketimpangan gender di DPRD Kota Yogyakarta. Ketimpangan besar terjadi pada kontrol dan manfaat bagi perempuan dalam setiap kegiatan yang diikutinya. Kedua, keunggulan perempuan dalam upaya pemberantasan korupsi tidak akan cukup berarti tanpa adanya kesetaraan gender.
\end{abstract}

Kata kunci: Gender, korupsi, DPRD, Kota Yogyakarta 


\section{Pendahuluan}

Praktik korupsi sudah begitu merusak tatanan governance di Indonesia. Penyalahgunaan wewenang dianggap sebagai praktik yang lumrah. Melihat kondisi tersebut, tidak heran kalau dalam tiga tahun terakhir lembaga riset Political and Economic Risk Consultancy selalu menempatkan Indonesia sebagai juara korupsi di Asia. Predikat serupa datang pula dari Transparency International yang selalu menempatkan Indonesia sebagai salah satu negara terkorup di dunia.

Berdasarkan pemahaman Pasal 2 UU No. 31 Tahun 1999 tentang Pemberantasan Tindak Pidana Korupsi sebagaimana diubah dengan UU No. 20 Tahun 2001 tentang Perubahan Atas Undang-Undang No. 31 Tahun 1999 tentang Pemberantasan Tindak Pidana Korupsi, korupsi adalah perbuatan secara melawan hukum dengan maksud memperkaya diri sendiri/orang lain (perseorangan atau korporasi) yang dapat merugikan keuangan/perekonomian negara). Korupsi dapat didefinisikan dengan berbagai cara. Walaupun demikian, bila dicermati secara teliti, akan diketahui bahwa hampir semua definisi korupsi mengandung dua unsur berikut sebagai satu kesatuan. Pertama, penyalahgunaan kekuasaan yang melampui batas kewajaran hukum oleh para pejabat atau aparatur negara; dan kedua, pengutamaan kepentingan pribadi atau klien di atas kepentingan publik oleh para pejabat atau aparatur negara yang bersangkutan ${ }^{1}$.

Korupsi dapat pula dilihat dari dimensi sosial budaya sehingga gender dan korupsi merupakan masalah terbaru dalam isu anti korupsi. Arah penelitian ke dalam dimensi gender korupsi difokuskan pada apakah gender berpengaruh dalam pemberantasan korupsi yang efektif. Sebagaimana telah dihasilkan dari suatu penelitian oleh Swamy et, all., yang menganalisis perbedaan gender dalam sikap penerimaan bentuk korupsi. Beberapa ahli juga telah mengusulkan bahwa perempuan dan laki-laki berhubungan dengan korupsi karena perbedaan dalam mengambil resiko perilaku. Hasil penelitian ini adalah peran khusus perempuan dalam masyarakat, yang mempercayakan mereka dengan anak-anak dan orang tua dalam keluarga, membuat mereka lebih menolak resiko².

Dari penjelasan di atas maka penting dilaksanakan penelitian untuk mengetahui pengaruh gender dalam pemberantasan korupsi di lembaga legislatif Yogyakarta.

\footnotetext{
${ }^{1}$ Mochtar Lubis dan James C. Scott, Bunga Rampai Korupsi, Jakarta, LP3ES, 1985, hlm. 10.

${ }^{2}$ Fernanda Rivas. December 2008. An Experiment on Corruption and Gender. hal 8-10 dalam http://ideas.repec.org/ $\mathrm{p} / \mathrm{gra} /$ wpaper/08-10.html diakses tanggal 21Desember 2011.
} 
Peran penting lembaga legislatif sebagai lembaga yang memiliki kewenangan dalam perumusan dan pengesahan kebijakan publik membuka peluang besar untuk terjadi korupsi. Secara empiris dibuktikan dengan sebanyak 12 orang mantan anggota DPRD Kota Yogyakarta periode 1999-2004 yang terlibat kasus korupsi Dana Purna Tugas (DPT) dijebloskan ke penjara 1 Februari 2012. ${ }^{3}$ Anggota DPRD DIY diduga melakukan korupsi APBD sejumlah 1,6 Milyar. ${ }^{4}$ Yogyakarta masih belum bersih dalam hal korupsi. Saat ini, Yogjakarta mendapat skor $(5,81)$ di bawah skor Denpasar, Tegal, dan Solo. Sedangkan nilai integritas daerah Kota Yogyakarta mendapat nomor urutan $3 .^{5}$

\section{Rumusan Masalah}

Berangkat dari berbagai persoalan tersebut, peneliti tertarik untuk mencermati dan menggali fenomena kesetaraan gender dalam pemberantasan korupsi di DPRD Kota Yogyakarta. Adapun permasalahan yang akan diteliti, pertama, bagaimana kesetaraan gender dalam upaya pemberantasan korupsi di DPRD Kota Yogyakarta? Kedua, apakah terdapat pengaruh kesetaraan gender terhadap upaya pemberantasan korupsi di DPRD Kota Yogyakarta?

\section{Tujuan Penelitian}

Secara umum penelitian ini bertujuan untuk mengetahui, pertama: profil kesetaraan gender dalam upaya pemberantasan korupsi di DPRD KotaYogyakarta; Kedua, pengaruh kesetaraan gender dalam upaya pemberantasan korupsi di DPRD Kota Yogyakarta. Penelitian ini diharapkan memberi wacana baru yang penting mendapat perhatian dalam agenda memberantas korupsi di Kota Yogyakarta.

\footnotetext{
${ }^{3}$ Rawira Maulana. 31 Januari 2012. 12 Mantan Anggota DPRD dijebloskan Penjara. Tribunjogja. Dalam http:/ /m.tribunnews.com/2012/01/31/12-mantan-anggota-dprd-yogyakarta-dijebloskan-penjara. Diakses tanggal 5 Februari 2012

${ }^{4}$ Detik. 02 Juni 2004. DPRD DIY diduga korupsi APBD 16 Milyar. Dalam (http://infokorupsi.com/id/ korupsi.php?ac $=567 \& \mathrm{l}=$ dprd-diy-diduga-korupsi-apbd-rp-16-miliar) diakses tanggal 5 Februari 2012.

${ }^{5}$ Farzana Nawaz. 2009. State of Research on Gender and Corruption. Nti Crruption Resource Centre. http://
} 


\section{Metode Penelitian}

Penelitian ini merupakan penelitian diskriptif. Penelitian diskriptif bermaksud mendiskripsikan suatu gejala berdasarkan pada indikator-indikator yang di jadikan dasar dari ada tidaknya suatu gejala yang di teliti. ${ }^{6}$

Konsep gender menurut Mansour Fakih ${ }^{7}$ adalah bahwa suatu sifat yang melekat pada kaum laki-laki maupun perempuan yang dikonstruksi secara sosial maupun kultural. Misalnya, perempuan dikenal lembut, emosional, sedangkan laki-laki dianggap kuat atau rasional. UNESCO mendefinisikan kesetaraan gender merupakan konsep yang menyatakan semua manusia (baik laki-laki maupun perempuan) bebas mengembangkan kemampuan personal mereka dan membuat pilihan-pilihan tanpa dibatasi oleh stereotype, peran gender yang kaku dan prasangka-prasangka. ${ }^{8}$

Indikator kesetaraan gender berupa akses, partisipasi, kontrol dan manfaat dalam posisi sebagai anggota legislatif. ${ }^{9}$ 1) akses adalah peluang atau kesempatan dalam memperoleh atau menggunakan sumber daya tertentu; 2) partisipasi adalah peran serta/keterlibatan dalam pengambilan keputusan; 3) kontrol adalah penguasaan atau wewenang atau kekuatan untuk mengambil keputusan; 4) manfaat adalah kegunaan sumber yang dapat dinikmati secara optimal.

Berdasarkan pendapat Robert Klitgaard ${ }^{10}$ dan Solmon ${ }^{11}$ bahwa upaya pemberantasan korupsi dipengaruhi oleh akuntabilitas dan etika. Peneliti menggunakan indikator akuntabilitas dan etika merujuk pada konsep pedoman Good Public Governance ${ }^{12}$. Upaya pemberantasan korupsi menggunakan aspek nilainilai, aspek etika penyelenggaraan negara, aspek pedoman perilaku, dan aspek akuntabilitas kinerja. Masing-masing indikator dalam setiap aspek seperti berikut: a) aspek nilai, indikatornya: integritas, profesionalisme, mengutamakan kepentingan masyarakat, berwawasan kedepan; b) aspek etika penyelenggaraan negara, indikatornya: perilaku individu, perlindungan terhadap harta milik negara,

\footnotetext{
${ }^{6}$ Y. Slamet, Metode Penelitian Sosial, Sebelas Maret University Press, 2006, hlm. 7.

${ }^{7}$ Mansour Fakih, Analisis Gender dan Transformasi, Pustaka Pelajar, Yogyakarta, 2007, hlm. 8.

${ }^{8}$ Ismi Dwi Astuti Nurhaeni, Kebijakan Publik Pro Gender, Surakarta, UPT Penerbitan dan Percetakan UNS (UNS Press), 2009, hlm. 33.

${ }^{9}$ Eva K Sundari, Advokasi Penganggaran Berbasis Kinerja Responsif Gender, Jakarta, PATTIRO dan The Asia Foundation, 2006, hlm. 110.

${ }^{10}$ Robert Klitgaard, Membasmi Korupsi (diterjemahkan oleh Hermoyo), Yayasan Obor Indonesia, Jakarta, 1998, hlm. 12 .

${ }^{11}$ Solmon dalam Deni, Saiful, Korupsi Birokrasi, Naufan Pustaka, Yogyakarta, 2010, hlm. 211.

${ }^{12}$ Komite Nasional Kebijakan Governance, Konsep Pedoman Good Public Governance, 2008.
} 
menghindari kepentingan pribadi; c) aspek pedoman perilaku. Indikatornya: kepatuhan terhadap aturan, kerahasiaan informasi, pelaksanaan kewenangan, pengungkapan dan pelaporan tindakan penyimpangan; d) aspek akuntabilitas, indikatornya: penilaian tupoksi DPRD, pertanggungjawaban tugas, anti gratifikasi, responsibilitas.

Penelitian ini menggunakan penggabungan data kuantitatif dan data kualitatif. Populasi dalam penelitian ini adalah anggota DPRD di Kota Yogyakarta. Pemilihan Sampel dalam penelitian ini menggunakan cluster berdasarkan fraksi di DPRD Kota Yogyakarta untuk dilakukan indept interview. Serta survey dilakukan kepada 30 anggota dewan merujuk pada pendapat Gay bahwa untuk penelitian diskriptif dapat menggunakan sampel minimal 30 responden $^{13}$. Dalam rangka memperoleh hasil lebih mendalam maka peneliti melakukan indept interview ke seluruh ketua fraksi di DPRD Kota Yogyakarta.

\section{Hasil Penelitian dan Pembahasan}

\section{Profil Anggota DPRD Kota Yogyakarta.}

Anggota DPRD Kota Yogyakarta terdiri dari 34 laki-laki dan 6 perempuan. Komposisi anggota DPRD memperlihatkan masih terdapat ketimpangan yang besar antara laki-laki dan perempuan. Prosentase anggota dewan perempuan hanya 15\% . Secara empiris jumlah anggota DPRD Kota Yogyakarta nampak pada tabel 1 berikut:

Tabel 1.

Komposisi anggota DPRD Kota Yogyakarta periode 2009-2014

\begin{tabular}{|l|c|c|}
\hline \multicolumn{1}{|c|}{ Partai } & Laki-laki & Perempuan \\
\hline PDIP & 10 & 1 \\
Partai Demokrat & 10 & 0 \\
PAN & 5 & 0 \\
PKS & 4 & 1 \\
GOLKAR & 3 & 2 \\
PPP & 1 & 1 \\
GERINDRA & 1 & 1 \\
\hline Jumlah & 34 & 6 \\
\hline
\end{tabular}

Sumber: DPRD Kota Yogyakarta

13 L.R. Gay \& P.L. Diehl, Research Methods for Business and Management, Simon \& Schuster (Asia) Pte Ltd, Singapore, 1996, hlm. 140-141. 
Kedudukan pimpinan DPRD seperti ketua DPRD, ketua komisi maupun ketua fraksi tidak ada satupun perempuan yang menduduki jabatan strategis tersebut. Hasil wawancara menyatakan di DPRD Kota Yogyakarta, kedudukan strategis sebagai pimpinan DPRD maupun pimpinan komisi dipilih dengan pertimbangan memiliki banyak pengalaman yang masih didominasi oleh laki-laki. Perempuan dianggap masih memiliki kapasitas yang rendah. Namun, posisi strategis juga menjadi perebutan semua anggota dewan. Oleh karena itu, hak tersebut sulit di peroleh perempuan karena arogansi laki-laki untuk menjadi pemimpin. Rendahnya representasi perempuan baik dari segi kuantitas maupun kualitas menunjukkan posisi lemah perempuan di parlemen.

Dalam kaitannya dengan pengambilan keputusan, menurut Sri Wiyanti ${ }^{14}$, perempuan masih menduduki posisi sebagai penunjang di dalam peran lembaga pemerintahan maupun lembaga non pemerintahan. Kenyataan tersebut dapat dilihat pada posisi yang ditempati perempuan dalam lembaga. Posisi yang kurang strategis oleh perempuan menyebabkan inisiatif perempuan menjadi terhambat.

Tujuan keberadaan perempuan dalam parlemen hendaknya dapat mempengaruhi proses politik yang terjadi di dalam parlemen dengan perspektif gender. Menurut Subono ${ }^{15}$ representasi politik perempuan menjadi sesuatu yang sangat penting karena tidak ada demokrasi sejati (no true democracy) dan tidak ada partisipasi masyarakat yang sesungguhnya (no true people's participation) dalam pemerintahan dan pembangunan, tanpa adanya partisipasi yang setara antara lakilaki dan perempuan. Oleh karena itu, kesetaraan gender sangat diperlukan.

\section{Kesetaraan dalam Upaya Pemberantasan Korupsi pada Anggota Dewan}

Fenomena korupsi saat ini banyak dikorelasikan dengan gender. Seperti halnya asumsi yang dibangun dari berbagai penelitian seperti David Dollar, Raymond Fisman, dan Roberta Gatti dalam hasil penelitian Bank Dunia tahun 1999 yang bertema "Are Woman Really The Fairer Sex; Corruption And Women In Government?. Dalam penelitian tersebut Dollar, Fisman, dan Gatti menyimpulkan women less corrupt atau wanita tidak terlalu korup.

${ }^{14}$ Sri Wiyanti, dkk., Kemandirian Perempuan dalam Pengambilan Keputusan pada Organisasi Publik Surakarta, Pusat Penelitian dan Pengembangan Gender Lembaga Penelitian Universitas Sebelas Maret Surakarta, 2004.

${ }^{15}$ Subono, Nur Iman, "Tokoh Politik Perempuan di Asia: Dinasti Politik atau Representasi Politik Perempuan?” 
Dalam pembahasan ini, peneliti telah mengukur upaya pemberantasan korupsi yang dilakukan oleh laki-laki dan perempuan. Upaya pemberantasan korupsi tersebut diukur melalui beberapa indikator, pertama: aspek nilai-nilai yang meliputi integritas, profesional, mengutamakan kepentingan masyarakat dan negara, serta berwawasan ke depan. Kedua, yaitu aspek etika penyelenggaraan negara yang meliputi perilaku individu, perlindungan harta milik negara, menghindari kepentingan pribadi. Ketiga, aspek akuntabilitas yang meliputi kepatuhan terhadap peraturan, kerahasiaan informasi, pelaksanaan kewenangan, pengungkapan dan pelaporan penyimpangan. Keempat, aspek akuntabilitas meliputi penilaian tupoksi DPRD, pertanggungjawaban tugas, anti gratifikasi, dan responsibilitas.

\section{Aspek Nilai-Nilai}

Nilai-nilai menggambarkan sikap moral penyelenggara negara dalam menjalankan amanah serta tanggung jawabnya dalam bermasyarakat, berbangsa dan bernegara. Apabila dilakukan penilaian maka dari aspek nilai-nilai nampak bahwa indikator integritas tidak jauh berbeda antara laki-laki dan perempuan, meskipun demikian integritas laki-laki dengan nilai 4,88 lebih tinggi sedikit dibanding perempuan dengan nilai 4,8. Tetapi dalam hal profesionalisme maka nilai perempuan sebesar 5 jauh lebih tinggi dibanding laki-laki yang memiliki nilai 4,88. Dalam hal pengutamakan kepentingan masyarakat dan negara ternyata lakilaki memiliki nilai 4,92 yang lebih tinggi dibanding perempuan yang bernilai 4,6. Sedangkan laki-laki dan perempuan sama-sama berwawasan ke depan dengan selisih nilai tidak jauh berbeda yaitu 4,84 untuk laki-laki dan 4,8 untuk perempuan. Perbedaan derajat nilai antara DPRD laki-laki dan DPRD perempuan dalam aspek nilai-nilai nampak pada gambar 1.

Dilihat dari aspek nilai-nilai ini nampak keunggulan dari masing-masing kelompok gender, yaitu kelompok laki-laki mendapat keunggulan dalam hal integritas dan mengutamakan kepentingan masyarakat dan negara. Sedangkan perempuan memiliki keunggulan dalam hal profesionalitas dibanding laki-laki. 
Gambar 1

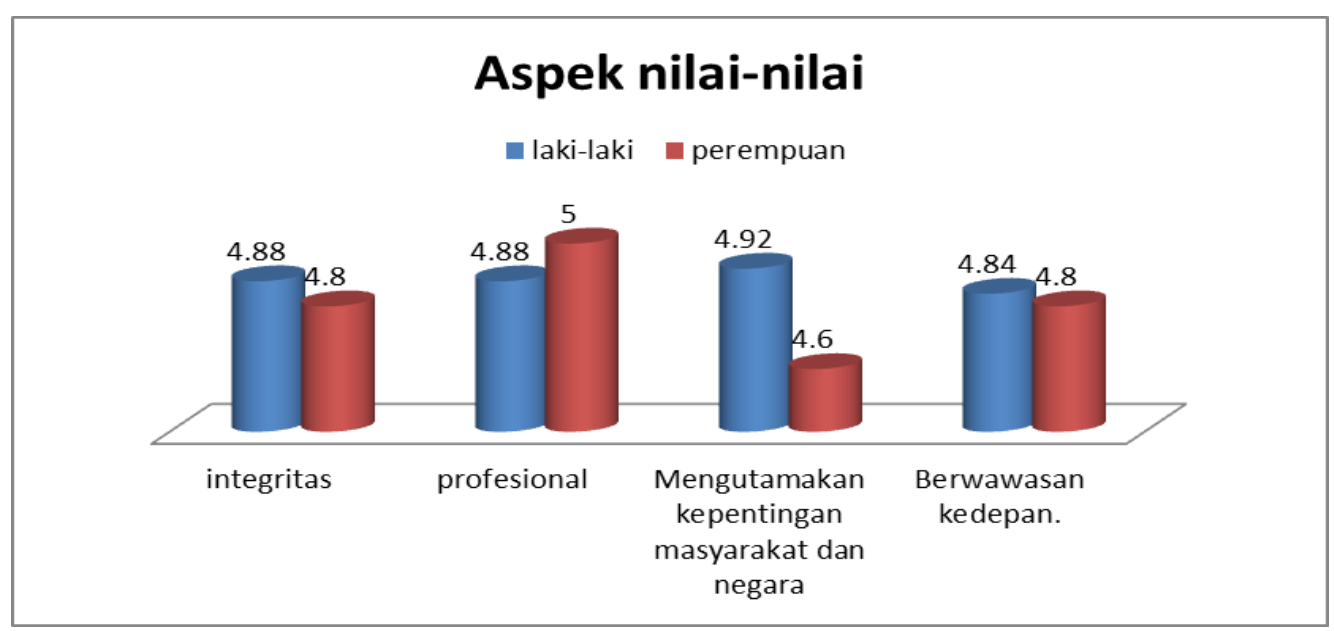

Sumber: diolah dari hasil survey

Aspek integritas lebih tinggi pada laki-laki karena pemahaman akan materi atau aturan telah menyebabkan mereka berkata dan berpikir didasarkan pada aturan. Lakilaki juga lebih mengutamakan kepentingan masyarakat dan negara daripada perempuan. Hal ini dapat dikaitkan dengan masalah gender bahwa konstruksi gender menempatkan perempuan memiliki tanggungjawab utama terhadap urusan rumah tangga (domestic). Dengan demikian, perempuan memiliki keterbatasan untuk memaksimalkan diri menjadi wakil rakyat. Keterbatasan itu dijelaskan melalui wawancara para dewan bahwa perempuan terpaksa tidak mengikuti beberapa kegiatan dewan yang berbenturan dengan tugas rumah atau kurang dukungan dari keluarga. Beban kerja rumah tangga terhadap perempuan ini dijelaskan oleh Riant Nugroho ${ }^{16}$ dan Umi Sumbullah ${ }^{17}$ sebagai korban dari adanya bias gender di tatanan masyarakat.

Aspek profesionalisme perempuan tinggi daripada laki-laki dikarenakan perempuan lebih memiliki komitmen dalam menyelesaikan pekerjaannya secara tuntas. Hasil wawancara menyatakan dalam pelaksanaan tugas-tugas DPRD banyak yang mengakui bahwa perempuan jauh lebih rajin dalam bekerja dibandingkan laki-laki.

\section{Aspek Etika Penyenggaraan Negara}

Etika merupakan acuan bagi penyelengara negara dalam melaksanakan tugasnya termasuk dalam berinteraksi dengan pemangku kepentingan dan masyarakat. Berdasarkan aspek etika penyelenggaraan negara nampak perbedaan laki-laki maupun perempuan seperti berikut:

\footnotetext{
${ }^{16}$ Riant Nugroho, Gender dan Strategi Pengarusutamaan di Indonesia, Yogyakarta, Pustaka Pelajar, 2008, hlm. 16.
}

${ }^{17}$ Umi Sumbullah, Gender dan Demokrasi, Averoes Press bekerjasama dengan Program Sekolah Demokrasi 
Gambar 2

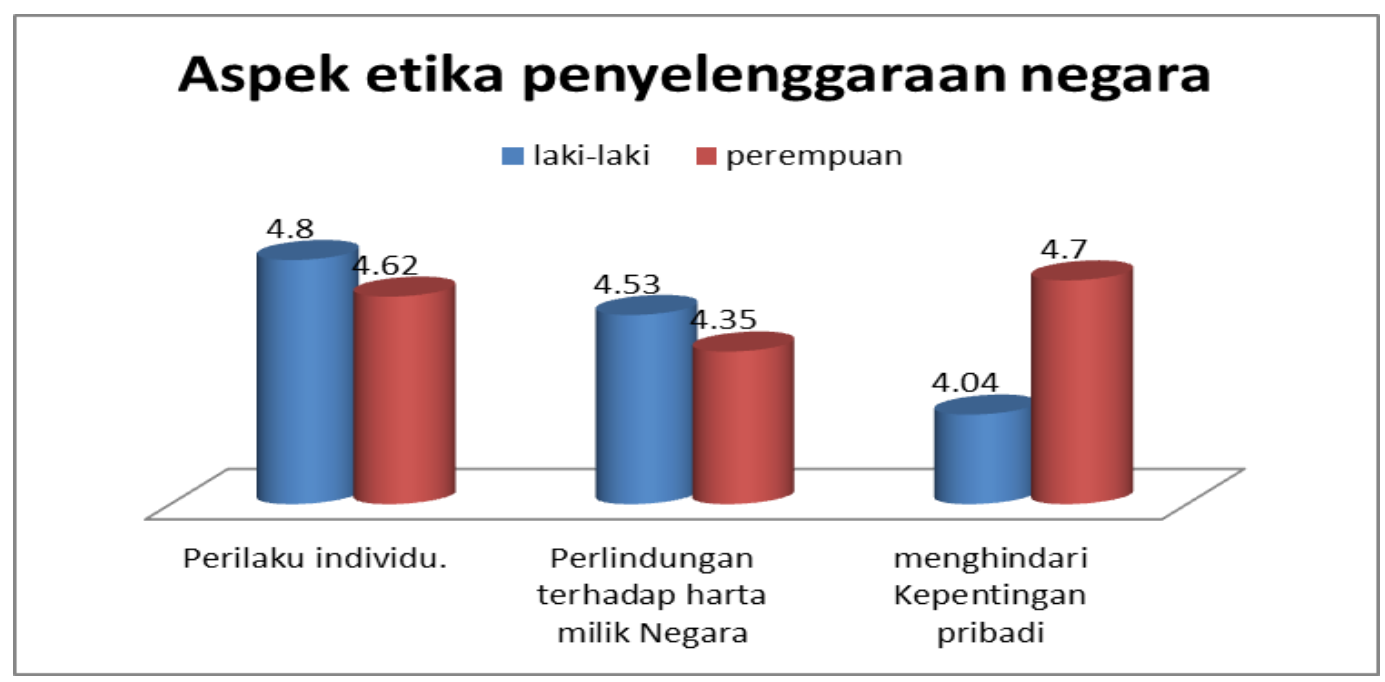

Sumber: diolah dari hasil survey

Apabila dilakukan penilaian maka aspek etika penyelenggaran negara, menunjukkan nilai perilaku individu laki-laki $(4,8)$ lebih tinggi dibanding nilai perempuan $(4,62)$. Laki-laki lebih bersikap melindungi harta negara dengan nilai 4,53 dibanding perempuan yang memiliki niai 4,35. Hal tersebut bukan berarti lakilaki cenderung tidak korupsi dibanding perempuan. Akan tetapi, modus korupsi di legislatif lebih bersifat kebijakan seperti halnya yang terjadi di Yogyakarta, melalui modus dana hibah dan bantuan sosial yang sasarannya ditujukan kepada para konstituennya. Korupsi ini memang tidak menggunakan harta negara untuk memperkaya diri sendiri, tetapi menyalahgunakan harta negara untuk kepentingan pribadi (menjaga suara konstituen).

Sebagaimana ini juga dijelaskan oleh $\mathrm{SH}$. Alatas ${ }^{18}$ bahwa inti korupsi adalah penyalahgunaan kepercayaan untuk kepentingan pribadi. Dalam hal menghindari kepentingan pribadi ternyata perempuan jauh memiliki nilai lebih tinggi dibanding laki-laki, dengan perbandingan 4,7 untuk perempuan dan 4,04 untuk laki-laki.

Dalam etika penyelenggaraan negara, kelompok perempuan dan laki-laki memiliki keunggulan masing-masing. Perempuan lebih unggul untuk menghindari kepentingan pribadi dalam menjalankan tugasnya sebagai dewan. Sementara lakilaki lebih unggul dalam hal perilaku individu dan perlindungan terhadap harta negara. Dari indikator perilaku tidak jauh berbeda antara perempuan dan laki-laki. Perempuan jauh lebih menghindari kepentingan pribadi dibanding laki-kaki. Hal ini

${ }^{18}$ SH. Alatas, Korupsi: Sifat, Sebab dan Fungsi, LP3ES, Jakarta, 1987, hlm. 1. 
sebagaimana diungkapkan dari wawancara dengan anggota dewan bahwa perempuan jauh lebih bersikap normatif dan berhati-hati. Temuan ini membuktikan argumen David Dollar bahwa perempuan cenderung tidak berperilaku opportunistically, maka membawa lebih banyak perempuan ke pemerintahan kemungkinan akan memiliki manfaat yang signifikan bagi masyarakat secara umum. ${ }^{19}$

\section{Aspek Pedoman Perilaku}

Pedoman perilaku mencakup panduan tentang kepatuhan terhadap peraturan, kerahasiaan informasi, pelaksanaan kewenangan serta hak dan kewajiban dalam pengungkapan tindakan penyimpangan. Berdasarkan aspek pedoman perilaku nampak bahwa antara laki-laki dan perempuan tidak jauh berbeda. Pada indikator kepatuhan terhadap peraturan menunjukkan laki-laki $(4,49)$ jauh sedikit lebih patuh dibanding perempuan $(4,4)$. Hal ini dikarenakan laki-laki lebih banyak yang memahami materi dari peraturan yang ada daripada dewan perempuan. Pengalaman menduduki jabatan DPRD lebih dari satu periode sangat mempengaruhi pemahaman anggota dewan laki-laki terhadap segala aturan. Di DPRD Kota Yogyakarta, anggota dewan perempuan semuanya merupakan orang baru. Hal inilah yang juga mempengaruhi pengungkapan penyimpangan pada kelompok perempuan $(4,4)$ cenderung lebih rendah dibanding laki-laki $(4,56)$. Namun, dalam hal kerahasiaan informasi dan pelaksanaan kewenangan ternyata perempuan jauh lebih tinggi daripada laki-laki.

\section{Gambar 3}

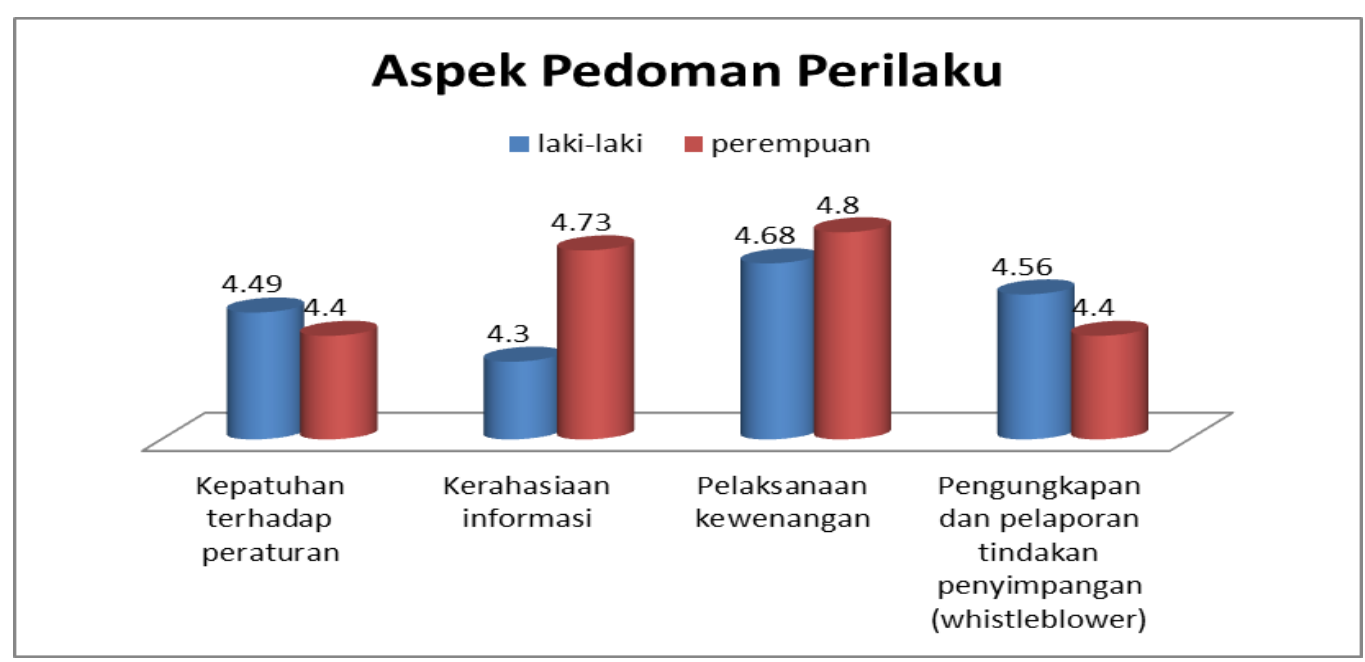

Sumber: diolah dari hasil survey

${ }^{19}$ David Dollar, et all. Are Women Really the "Fairer" Sex? Corruption and Women in Governance. October 1999. The World Bank, Policy Research Report On Gender and Development.Dalamhttp://citeseerx.ist.psu.edu/viewdoc/ download?doi=10.1.1.199.5857\&rep=rep1\&type=pdf, diakses tanggal 21 Desember 2011. 
Kepatuhan terhadap aturan akan sangat terkait dengan pemahaman materi pada para anggota DPRD. Dalam kasus ini, kurangnya penguasaan pemahaman materi terdapat pada anggota DPRD perempuan. Hal ini dikarenakan, pertama, masingmasing perempuan di DPRD Kota Yogyakarta masih baru menjabat sebagai dewan. Kedua, waktu untuk mempelajari peraturan perundang-undangan dirasakan kurang karena mereka memiliki beban ganda yang tidak dimiliki laki-laki. Perempuan biasanya terbebani pekerjaan domestik, seperti setelah pulang kantor masih mengerjakan pekerjaan rumah tangga,dan masih mengurusi anak-anak dan suami.

Dari hasil wawancara dengan anggota dewan juga diketahui bahwa pemahaman materi dan kapasitas perempuan tidaklah lebih baik daripada laki-laki. Hal ini juga dikarenakan kurangnya pendidikan politik bagi kaum perempuan sehingga dari segi kualitas perempuan di parlemen ternyata juga masih menjadi persoalan.

Menurut Ruslan, ${ }^{20}$ partai politik menjadi media pendidikan politik yang sesungguhnya karena kehidupan partai termasuk media pelatihan individu untuk berani mengambil keputusan serta menyiapkan kemampuan bersikap kritis . Diakui oleh anggota dewan khusus perempuan bahwa pendidikan dan pelatihan yang diadakan oleh partai politik secara eksplisit masih belum mengarah ke pengarustamaan gender. Hal ini disebabkan oleh rendahnya tingkat kesadaran kritis kader perempuan dan kurangnya partisipasi perempuan dalam menduduki posisi struktural partai.

Keunggulan perempuan dalam menjaga kerahasiaan sangat dipengaruhi oleh sikap perempuan yang lebih berhati-hati. Sedangkan keunggulan perempuan dalam melakanakan kewenangannya dikeranakan perempuan dalam melaksanakan tugas dan kewenangannya lebih sering sesuai dengan uraian tugas yang berlaku baginya. Hal ini juga membuktikan alasan sebelumnya yang menyatakan perempuan lebih bersikap normatif.

\section{Aspek Akuntabilitas}

Akuntabilitas dapat merupakan pengetahuan dan adanya pertanggungjawaban terhadap setiap tindakan, keputusan dan kebijakan. Berdasarkan aspek akuntabilitas nampak bahwa dalam hal pelaksanaan tugas pokok dan fungsi (tupoksi) DPRD ternyata kelompok perempuan dengan nilai 4,6 lebih unggul dibanding laki-laki dengan nilai 4.4. Hal ini berdasarkan hasil wawancara dikarenakan kelompok

${ }^{20}$ U. AM Ruslan, Pendidikan Politik Ikhwanul Muslimin, Era Intermedia, Solo, 2000, hlm. 109. 
perempuan lebih cermat dan rajin dibanding laki-laki untuk merinci tugas-tugasnya dengan jelas. Dalam hal pertanggungjawaban tugas ternyata perempuan jauh memiliki nilai yang lebih dibanding laki-laki yaitu 4.4 dibanding 3.4. Sedangkan untuk persoalan anti gratifikasi nampak bahwa perempuan dengan nilai 4,1 jauh lebih unggul dibanding laki-laki yang memiliki nilai 3,48. Dalam hal responsibilitas menunjukkan perempuan jauh lebih unggul dibanding laki-laki. Hal ini dikarenakan kedekatan perempuan dengan urusan rumah tangga membuat perempuan lebih responsif terhadap kebutuhan dasar manusia seperti pendidikan, kesehatan perlindungan anak dan perempuan.

\section{Gambar 4}

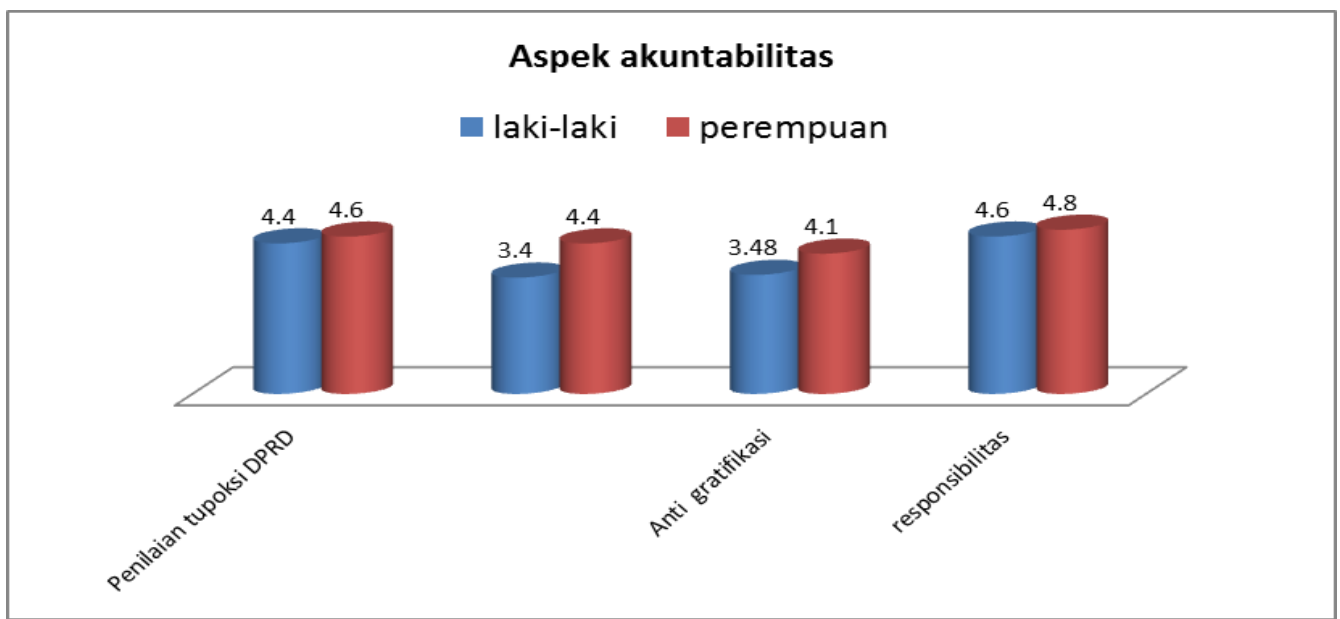

Sumber: diolah dari hasil survey

Pelaksanaan akuntabilitas kinerja perempuan lebih unggul dibanding laki-laki dikarenakan anggota dewan perempuan di DPRD Kota Yogyakarta lebih memiliki akuntabilitas kinerja yang baik. Hasil wawancara menyatakan responsibilitas perempuan cenderung lebih besar karena kedekatan perempuan dengan kebutuhan dasar masyarakat seperti pendidikan dan kesehatan.

Perempuan memiliki perilaku anti gratifikasi sehingga perempuan sulit untuk disuap. Hal ini mendukung argumen Fernanda Rivas, bahwa perempuan cenderung lebih sulit untuk disuap. Hasil penelitiannya menunjukkan rata-rata frekuensi suap menyuap lebih tinggi ditawarkan ketika f (pengusaha) adalah seorang pria. Suap lebih sering diterima ketika mereka datang dari f (pengusaha) laki-laki, sementara tingkat terendah penerimaan diamati ketika PO (pejabat publik) perempuan dipasangkan dengan F (pengusaha) Perempuan. ${ }^{21}$

\footnotetext{
${ }^{21}$ Fernanda Rivas. 2008. An Experiment on Corruption and Gender. Hlm. 8-10 dalam http://ideas.repec.org/p/ gra/wpaper/08-10.html, diakses tanggal 21 Desember 2011.
} 


\section{Akses dan Partisipasi Dewan Perempuan dan Dewan Laki-laki di DPRD Kota Yogyakarta dalam Kegiatan}

Dari hasil survey tersebut menunjukkan bahwa di DPRD Kota Yogyakarta tidak terdapat persoalan akses di setiap kegiatan DPRD untuk laki-laki maupun perempuan. Hal ini dibuktikan dengan tidak adanya dewan perempuan dan dewan laki-laki yang tidak pernah $(0 \%)$ mengikuti kegiatan di DPRD Kota Yogyakarta. Semua kelompok memiliki akses yang sama. Akan tetapi, terdapat tingkat partisipasi yang berbeda baik laki-laki maupun perempuan di kegiatan DPRD kota Yogyakarta. Hampir di seluruh kegiatan menunjukkan perempuan cenderung memiliki nilai partisipasi lebih tinggi dari laki-laki. Laki-laki hanya lebih aktif dalam pembahasan kebijakan umum APBD (KUA). Sedangkan perempuan aktif dalam kegiatan evaluasi APBD, pembahasan rancangan Perda APBD, penyusunan perda prakarsa sendiri dan penyusunan produk hukum.

\section{Gambar 5}

Nilai Partisipasi Dewan Perempuan dan Dewan Laki-laki di DPRD Kota Yogyakarta

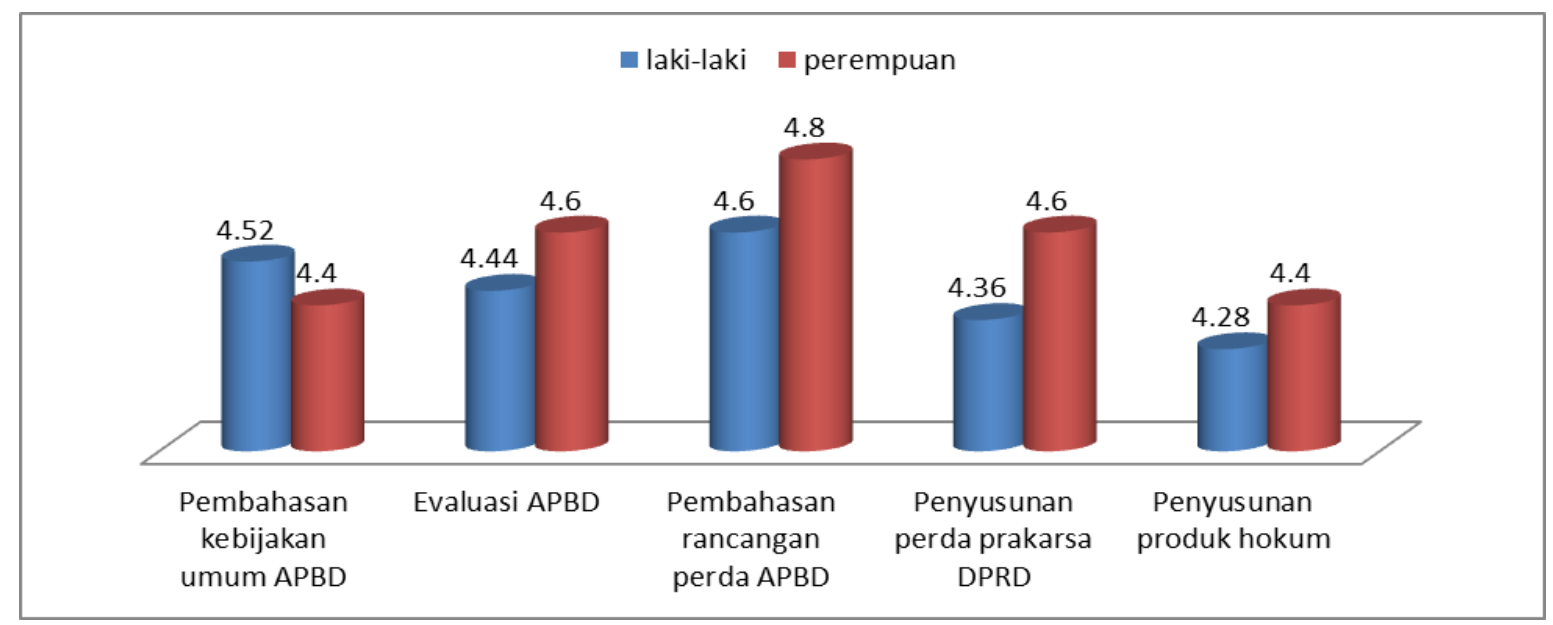

Sumber: hasil survey

Dalam pembahasan kebijakan umum APBD (KUA) nilai partisipasi laki-laki $(4,52)$ lebih tinggi daripada perempuan $(4,4)$ karena laki-laki selalu mengikuti kegiatan ini dan selalu memberikan pendapatnya. Sedangkan perempuan hanya kadang-kadang memberikan pendapatnya saja. Dalam pembahasan KUA PPAS yang paling berperan aktif adalah badan anggaran, sehingga ketua dan anggota badan anggaran yang cenderung banyak memberikan pendapatnya. Keanggotaan perempuan dalam badan anggaran ini hanya terdiri 2 orang saja dari 18 orang anggota badan anggaran. 
Di dalam evaluasi APBD, pembahasan rancangan APBD penyusunan perda prakarsa sendiri, dan penyusunan produk hukum menunjukkan nilai partisipasi perempuan yang lebih tinggi daripada laki-laki. Pada evaluasi APBD diketahui nilai perempuan sebesar 4,6 sedangkan nilai partisipasi laki-laki hanya 4,4. Pada kegiatan pembahasan rancangan perda APBD nilai partisipasi perempuan sebesar 4,8 , sedangkan nilai partisipasi laki-laki hanya 4,6. Dalam kegiatan penyusunan perda prakarsa sendiri nilai partisipasi perempuan sebesar 4,36 sedangkan nilai partisipasi laki-laki 4,36. Nilai partisipasi rendah pada laki-laki ini karena terdapat anggota dewan laki-laki yang tidak menghadiri atau hanya kadang-kadang menghadiri kegiatan tersebut.

Apabila dilihat dalam bentuk prosentase keaktifan dalam berpartisipasi maka nampak bahwa dewan laki-laki lebih tinggi keaktifannya pada 2 kegiatan saja, sedangkan perempuan berpartisipasi lebih tinggi dari laki-laki dalam 3 kegiatan. Prosentase akses dan partisipasi dewan perempuan dan dewan laki-laki nampak pada tabel berikut:

Tabel 3

Prosentase akses dan partisipasi dewan perempuan dan dewan laki-laki di DPRD Kota Yogyakarta

\begin{tabular}{|c|c|c|c|c|c|c|c|c|c|c|}
\hline \multirow[t]{2}{*}{ Kegiatan Dewan } & \multicolumn{2}{|c|}{$\begin{array}{c}\text { Pembahasan } \\
\text { kebijakan } \\
\text { umum APBD }\end{array}$} & \multicolumn{2}{|c|}{$\begin{array}{l}\text { Evaluasi } \\
\text { APBD }\end{array}$} & \multicolumn{2}{|c|}{$\begin{array}{c}\text { Pembahasan } \\
\text { rancangan } \\
\text { perda APBD }\end{array}$} & \multicolumn{2}{|c|}{$\begin{array}{l}\text { Penyusunan } \\
\text { perda prakarsa } \\
\text { DPRD }\end{array}$} & \multicolumn{2}{|c|}{$\begin{array}{l}\text { Penyusunan } \\
\text { produk } \\
\text { hukum }\end{array}$} \\
\hline & $\mathrm{L}$ & $\mathrm{P}$ & $\mathrm{L}$ & $\mathrm{P}$ & $\mathrm{L}$ & $\mathrm{P}$ & $\mathrm{L}$ & $\mathrm{P}$ & $\mathrm{L}$ & $\mathrm{P}$ \\
\hline $\begin{array}{l}\text { Selalu mengikuti } \\
\text { dan selalu } \\
\text { m e m b e r i a n } \\
\text { pendapat }\end{array}$ & $60 \%$ & $40 \%$ & $64 \%$ & $60 \%$ & $68 \%$ & $80 \%$ & $48 \%$ & $60 \%$ & $40 \%$ & $60 \%$ \\
\hline $\begin{array}{l}\text { Selalu mengikuti } \\
\text { dan kadang- } \\
\text { k a d a n g } \\
\text { me m berikan } \\
\text { pendapat }\end{array}$ & $36 \%$ & $60 \%$ & $20 \%$ & $40 \%$ & $24 \%$ & $20 \%$ & $40 \%$ & $40 \%$ & $52 \%$ & $20 \%$ \\
\hline $\begin{array}{l}\text { Kadang-kadang } \\
\text { mengikuti dan } \\
\text { memberikan } \\
\text { pendapat }\end{array}$ & $0 \%$ & $0 \%$ & $12 \%$ & $0 \%$ & $8 \%$ & $0 \%$ & $12 \%$ & $0 \%$ & $4 \%$ & $20 \%$ \\
\hline $\begin{array}{l}\mathrm{K} \text { a d a } \mathrm{n} \\
\text { mengikuti dan } \\
\mathrm{k} \text { a d a n g } \\
\text { memberikan } \\
\text { pendapat }\end{array}$ & $4 \%$ & $0 \%$ & $4 \%$ & $0 \%$ & $0 \%$ & $0 \%$ & $0 \%$ & $0 \%$ & $4 \%$ & $0 \%$ \\
\hline Tidak mengikuti & $0 \%$ & $0 \%$ & $0 \%$ & $0 \%$ & $0 \%$ & $0 \%$ & $0 \%$ & $0 \%$ & $0 \%$ & $0 \%$ \\
\hline
\end{tabular}

Sumber: hasil survey 
Dalam kegiatan DPRD diketahui dewan perempuan cenderung lebih aktif menghadiri kegiatan dan juga mengutarakan pendapatnya dibanding laki-laki. Sedangkan laki-laki cenderung bersikap lebih aktif dalam kegiatan yang berkaitan dengan APBD seperti pembahasan KUA APBD dan evaluasi APBD. Pembahasan KUA merupakan pembahasan yang paling strategis di dalam penentuan kebijakan anggaran. Namun, dewan perempuan cenderung kurang banyak memberikan pendapatnya dalam kegiatan ini. Rendahnya partisipasi perempuan untuk mengutarakan pendapat juga dikarenakan kemampuan perempuan dalam pembahasan kebijakan makro masih kurang.

\section{Kontrol Dewan Perempuan dan Dewan Laki-Laki di DPRD Kota Yogyakarta}

Dari hasil survey menunjukkan bahwa terdapat persoalan ketimpangan gender dalam kontrol (pengendalian) pada perempuan di setiap kegiatan DPRD. Sebagaimana dinyatakan bahwa perempuan cenderung memberikan pendapat akan tetapi pendapat tersebut jarang dilaksanakan. Pada kegiatan pembahasan kebijakan umum APBD sebagian besar dewan laki-laki menyatakan pendapat mereka sering dilaksanakan.

\section{Gambar 6}

Nilai kontrol dewan perempuan dan dewan laki-laki di DPRD Kota Yogyakarta

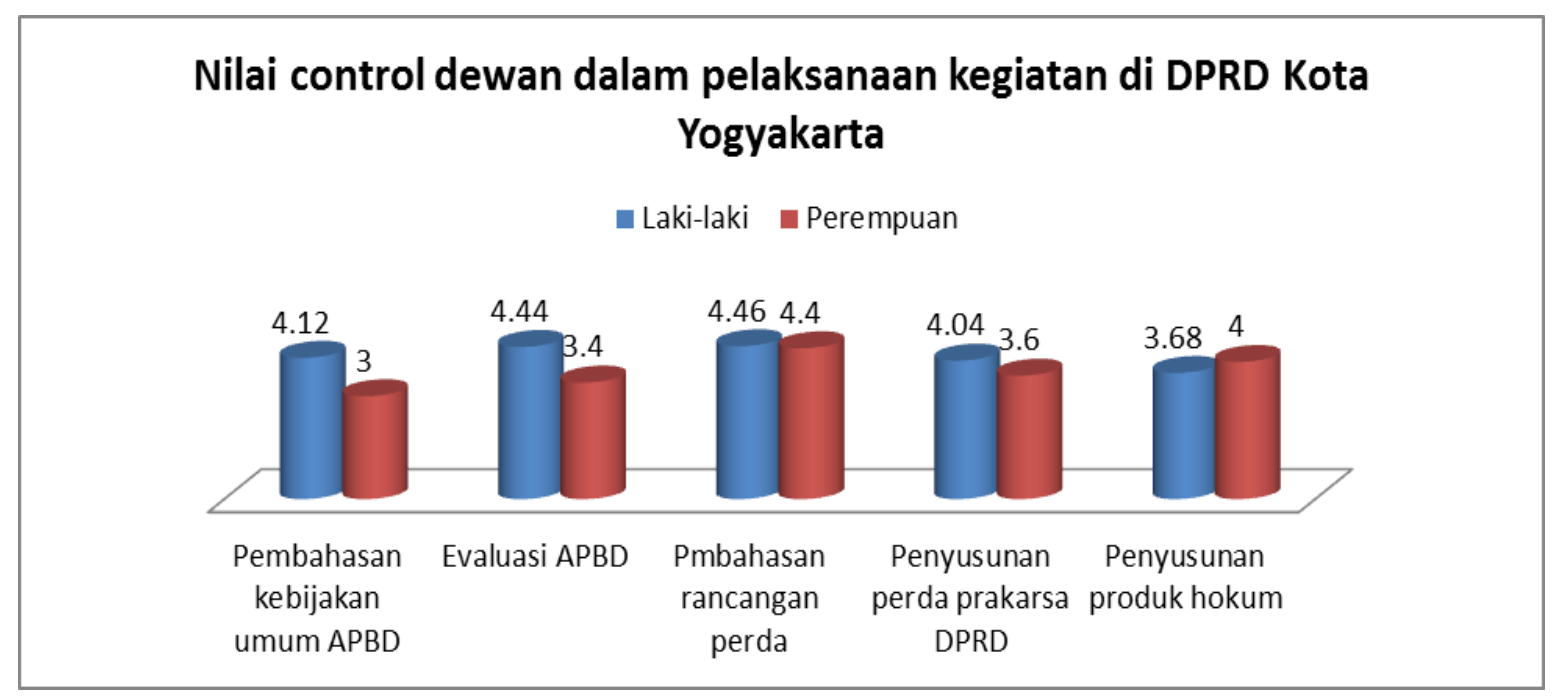

Sumber: Hasil survey

Nilai kontrol dewan laki-laki cenderung lebih tinggi dibanding dengan dewan perempuan pada kegiatan pembahasan KUA, evaluasi APBD, pembahasan rancangan $A P B D$, penyusunan perda prakarsa sendiri. Sedangkan pada penyusunan produk hukum nilai kontrol perempuan jauh lebih tinggi.

Apabila dilihat dalam prosentase partisipasi maka nampak diseluruh kegiatan 
dewan laki-laki cenderung lebih memiliki kontrol tinggi dibandingkan perempuan. Dewan laki-laki cenderung memberikan pendapatnya dan pendapat tersebut sering dilaksanakan. Berbeda halnya dengan dewan perempuan di mana pendapatnya jarang dilaksanakan. Prosentase kontrol dewan perempuan dan laki-laki nampak pada tabel berikut:

Berdasarkan temuan pada aspek kontrol tersebut dinyatakan bahwa kelompok

Tabel 4

Prosentase Kontrol Dewan Perempuan dan Dewan laki-laki di DPRD Kota Yogyakarta

\begin{tabular}{|c|c|c|c|c|c|c|c|c|c|c|}
\hline \multirow[t]{2}{*}{ Kegiatan Dewan } & \multicolumn{2}{|c|}{$\begin{array}{l}\text { Pembahasan } \\
\text { kebijakan } \\
\text { umum APBD }\end{array}$} & \multicolumn{2}{|c|}{$\begin{array}{l}\text { Evaluasi } \\
\text { APBD }\end{array}$} & \multicolumn{2}{|c|}{$\begin{array}{l}\text { Pembahasan } \\
\text { rancangan } \\
\text { perda }\end{array}$} & \multicolumn{2}{|c|}{$\begin{array}{l}\text { Penyusunan } \\
\text { perda prakarsa } \\
\text { DPRD }\end{array}$} & \multicolumn{2}{|c|}{$\begin{array}{l}\text { Penyusunan } \\
\text { produk } \\
\text { hukum }\end{array}$} \\
\hline & $\bar{L}$ & $\bar{P}$ & $\mathrm{~L}$ & $\mathrm{P}$ & $\mathrm{L}$ & $\bar{P}$ & $\bar{L}$ & $\bar{P}$ & $\mathrm{~L}$ & $P$ \\
\hline $\begin{array}{l}\text { SelaluMemberikan } \\
\text { pendapat dan } \\
\text { pendapat tersebut } \\
\text { sering dilaksankan }\end{array}$ & $60 \%$ & $40 \%$ & $72 \%$ & $20 \%$ & $68 \%$ & $60 \%$ & $59 \%$ & $20 \%$ & $40 \%$ & $20 \%$ \\
\hline $\begin{array}{l}\text { M e m b e } \mathrm{r} \text { a } \mathrm{n} \\
\text { pendapat dan } \\
\text { pendapat tersebut } \\
\text { jarang dilaksanakan }\end{array}$ & $4 \%$ & $20 \%$ & $4 \%$ & $40 \%$ & $12 \%$ & $40 \%$ & $9 \%$ & $40 \%$ & $4 \%$ & $60 \%$ \\
\hline $\begin{array}{l}\text { Kadang mem- } \\
\text { berikan pendapat } \\
\text { tapi pendapat } \\
\text { tersebut sering } \\
\text { dilaksanakan }\end{array}$ & $32 \%$ & $40 \%$ & $20 \%$ & $0 \%$ & $20 \%$ & $0 \%$ & $27 \%$ & $20 \%$ & $40 \%$ & $20 \%$ \\
\hline $\begin{array}{l}\text { Kadang mem- } \\
\text { berikan pendapat } \\
\text { tapi pendapat } \\
\text { tersebut jarang } \\
\text { dilaksanakan }\end{array}$ & $4 \%$ & $0 \%$ & $4 \%$ & $40 \%$ & $4 \%$ & $0 \%$ & $5 \%$ & $20 \%$ & $16 \%$ & $0 \%$ \\
\hline $\begin{array}{l}\text { Tidak memberikan } \\
\text { pendapat sama } \\
\text { sekali }\end{array}$ & $0 \%$ & $0 \%$ & $0 \%$ & $0 \%$ & $0 \%$ & $0 \%$ & $0 \%$ & $0 \%$ & $0 \%$ & $0 \%$ \\
\hline
\end{tabular}

Sumber: hasil survey

perempuan memiliki kontrol/pengendalian yang lemah atas segala pendapatnya. Hal ini dikarenakan peremuan memiliki kemampuan lobby yang kurang dan lakilaki juga cenderung lebih bersikap berani untuk mencapai tujuan dengan berbagai cara.

Berdasarkan analisis temuan mengenai profil anggota dewan baik perempuan dan laki-laki dalam upaya pemberantasan korupsi dapat diperoleh intisari sebagaimana tertera dalam matrik berikut: 
Tabel 5

Matrik Temuan Profil Kesetaraan Gender Dalam Upaya Pemberantasan Korupsi

\begin{tabular}{|c|c|c|c|}
\hline Variable & Aspek & Laki-laki & Perempuan \\
\hline $\begin{array}{l}U \underset{p}{\mathrm{p}} \text { a } \mathrm{y} \text { a } \\
\text { pemberantasan } \\
\text { korupsi }\end{array}$ & $\begin{array}{l}\mathrm{E} \mathrm{t} \mathrm{i} \mathrm{k} \text { a } \\
\text { penyelenggaraan } \\
\text { Negara } \\
\text { P e d o m a } \mathrm{n} \\
\text { perilaku }\end{array}$ & 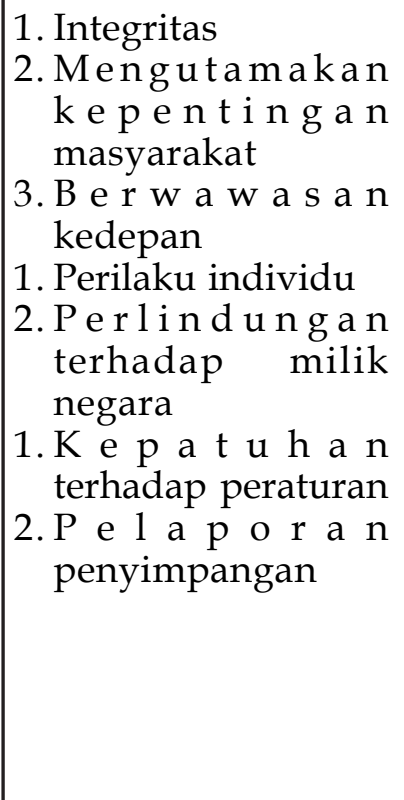 & $\begin{array}{l}\text { 1. M e } \mathrm{n} g \mathrm{~h} \text { i } \mathrm{n} \mathrm{d} \text { a } \mathrm{r} \mathrm{i} \\
\text { kepentingan pribadi } \\
\text { 1. Kerahasiaan informasi } \\
\text { 2. P e } 1 \text { a } \mathrm{k} \text { a } \mathrm{n} \text { a a } \mathrm{n} \\
\text { kewenangan } \\
\text { 1. Penilaian tupoksi } \\
\text { 2. Pertanggungawaban } \\
\text { tugas } \\
\text { 3. Anti gratisikasi } \\
\text { 4. Responsibilitas }\end{array}$ \\
\hline $\begin{array}{l}\text { Kes et a r a a n } \\
\text { Gender }\end{array}$ & $\begin{array}{l}\text { Kontrol dan } \\
\text { Manfaat }\end{array}$ & $\begin{array}{l}\text { Tidak ada persoalan } \\
\text { Partisipasi aktif di } \\
\text { kebijakan KUA } \\
\\
\text { Perempuan memiliki } \\
\text { k o n t r o l / } \\
\text { pengendalian yang } \\
\text { lemah atas segala } \\
\text { p e n d a p a t n y a } \\
\text { s e h i n g g a } \\
\text { pendapatnya sering } \\
\text { tidak diterima }\end{array}$ & $\begin{array}{l}\text { Tidak ada persoalan } \\
\text { Partisipasi aktif di } \\
\text { evaluasi APBD, } \\
\text { penyusunan dan } \\
\text { pembahasan perda APBD } \\
\text { dan produk hukum } \\
\text { Laki-laki memiliki kontrol } \\
\text { yang tinggi atas segala } \\
\text { pendapatanya sering } \\
\text { diterima. }\end{array}$ \\
\hline
\end{tabular}

Sumber: Hasil survey

Berdasarkan matrik tersebut diketahui bahwa perempuan lebih berperilaku mendukung upaya pemberantasan korupsi daripada laki-laki. Hal ini terlihat dari banyaknya indikator yang dimiliki perempuan dalam pemberantasan korupsi yang lebih unggul dibanding laki-laki (9 indikator untuk perempuan dan 7 indikator untuk laki-laki). Sehingga pernyataan bahwa women less corrupt yang artinya perempuan memliki sifat korupsi yang lebih rendah dibanding laki-laki benar adanya dari hasil penelitian ini. Sedangkan dari aspek kesetaraan gender nampak bahwa akses perempuan dan laki-laki tidak berbeda. Namun, partisipasi laki-laki jauh lebih aktif pada persoalan anggaran dibanding perempuan. Hal ini 
menunjukkan bahwa laki-laki memiliki kepentingan lebih besar pada persoalan anggaran dibanding perempuan. Persoalan anggaran inilah yang sangat riskan terjadinya korupsi.

Ketimpangan besar terjadi pada setiap kegiatan DPRD Kota Yogyakarta. Dengan demikian, jelas nampak bahwa ketimpangan gender ada dalam kegiatan di DPRD dimana masih adanya dominasi laki-laki di DPRD Kota Yogyakarta. Hal tersebut berkaitan dengan ketimpangan akan kapasitas laki-laki dalam bernegosiasi jauh lebih hebat dibanding perempuan dalam melaksanakan tupoksi dan laki-laki memiliki pemahaman mengenai materi aturan lebih baik dibanding perempuan. Adanya ketimpangan gender yang tinggi di DPRD Kota Yogyakarta menyebabkan potensi perempuan dalam pemberantasan korupsi tidak cukup berarti.

\section{Pengaruh Kesetaraan Gender terhadap Upaya Pemberantasan Korupsi}

Kesetaraan gender diukur dari adanya akses, partisipasi, kontrol dan manfaat dari setiap kegiatan yang diperoleh anggota dewan. sedangkan upaya pemberantasan korupsi diukur dengan aspek nilai-nilai, aspek etika penyelenggaraan negara, aspek pedoman perilaku dan aspek akuntabilitas. Dari hasil interpretasi analisis regresi linier yang telah dilakukan, maka diperoleh hasil persamaan regresi linier sebagai berikut:

$$
\mathrm{Y}=98.671+1.083 \mathrm{X} 1
$$

Tabel. 6.

Hasil Analisa Regresi Berganda

\begin{tabular}{|l|c|c|c|}
\hline \multicolumn{1}{|c|}{ Variabel } & Koefisien Regresi & t hitung & $\begin{array}{c}\text { Prob. (sig. } \mathrm{t}) \\
(\mathrm{a}=0,05)\end{array}$ \\
\hline $\mathrm{X}_{1}$ (Kesetaraan Gender) & 1.083 & 2.867 & 0.008 \\
Konstata & 98.671 & & \\
F hitung & 8.219 & & \\
Adjust ${ }^{2}$ & 0.199 & & \\
R Square $\left(\mathrm{R}^{2}\right)$ & 0,227 & & \\
$\mathrm{R}$ & 0,476 & & \\
\hline
\end{tabular}

Variabel terikat $=\mathrm{Y}($ Upaya Pemberantasan Korupsi)

Sumber: Data primer olahan output regresi linier berganda (2012)

Dari persamaan regresi tersebut nilai konstanta sebesar 98.671 yang berarti bahwa jika variabel independen yang terdiri atas Kesetaraan Gender (X1), sama dengan nol, maka nilai upaya pemberantasan korupsi (Y) akan terjadi peningkatan sebesar 98.671. Kesetaraan Gender $\left(X_{2}\right)$ mempunyai pengaruh yang positif terhadap 
upaya pemberantasan korupsi di legislatif (Y) dengan koefisien regresi sebesar 1.083 yang artinya apabila variabel pemberdayaan gender meningkat 1 satuan, maka upaya pemberantaan korupsi di legislatif akan meningkat sebesar 1.083 satuan dengan asumsi variabel jenis kelamin $\left(X_{1}\right)$ tetap. Hal ini menunjukkan bahwa variabel kesetaraan gender yang terdapat kaitannya dengan kapasitas ternyata cenderung mendukung upaya pemberantasan korupsi di DPRD Kota Yogyakarta.

Nilai R square $\left(\mathrm{R}^{2}\right)$ menunjukkan variabel independen mempengaruhi sebesar $22,7 \%$ terhadap variable terikat. Hal ini berarti variabel-variabel dalam penelitian dapat mempengaruhi secara dominan terhadap upaya pemberantaan korupsi, sedangkan sisanya sebesar 77,3\% dipengaruhi oleh variabel-variabel diluar yang diteliti.

Melalui Uji F didapatkan hasil $\mathrm{F}_{\text {hitung }}$ sebesar 8.219 dengan tingkat signifikan 0.008 , serta df penyebut 1 dan df pembilang sebesar 28 . Sebagaimana dapat dilihat Tabel 7 Anova

ANOVA $^{b}$

\begin{tabular}{|l|l|l|l|r|c|}
\hline \multicolumn{1}{|c|}{ Model } & Sum of Squares & \multicolumn{1}{c|}{ df } & Mean Square & F & Sig. \\
\hline 1 Regression & 1034.704 & 1 & 1034.704 & 8.219 & $.008^{\mathrm{a}}$ \\
Residual & 3524.763 & 28 & 125.884 & & \\
Total & 4559.467 & 29 & & & \\
\hline
\end{tabular}

dalam tabel 7 heading anova berkut:

a. Predictors: (Constant), kesetaraan gender

b. Dependent Variable: upaya pemberantasan korupsi

Nilai probabilitas < a maka variabel bebas berpengaruh terhadap variabel terikat, dengan demikian hipotesis teruji secara statistik. Dengan demikian tingkat signifikansi pada analisis ini sebesar 0,011<0,05, sehingga variabel independent (kesetaraan gender) mempengaruhi variabel dependent (upaya pemberantasan

Pengujian hipotesis kedua diketahui hasil koefisien $t_{\text {hitung }}$ menunjukkan bahwa Pengaruh kesetaraan gender terhadap upaya pemberantasan korupsi menunjukkan pengaruh nyata sebesar 0,008.

Tabel 8.

Perbandingan $t_{\text {hitung }}$ dengan Taraf Signifikan (á = 5\%)

\begin{tabular}{|c|c|l|l|l|l|}
\hline \multirow{2}{*}{ Model } & \multirow{2}{*}{$\mathrm{T}$} & \multirow{2}{*}{ Sig. } & \multicolumn{3}{|c|}{ Correlations } \\
\cline { 4 - 6 } & & & Zero-order & Partial & \multicolumn{1}{c|}{ Part } \\
\hline 1 (Constant) & 6.075 & .000 & .476 & .476 & .476 \\
\hline kesetaraan gender & 2.867 & .008 & & & \\
\hline
\end{tabular}

Sumber: Data primer olahan, 2012. 
Hasil pengujian tersebut menyatakan bahwa upaya pemberantasan korupsi secara nyata dipengaruhi oleh kesetaraan gender terutama bagaimana akses, partisipasi, manfaat dan kontrol dari anggota dewan dalam setiap pelaksaaan tugasnya. Potensi keunggulan yang ada pada laki-laki maupun perempuan dalam pemberantasan korupsi di legislatif tidak akan cukup berarti apabila tidak ada kesetaraan gender di dalam legislatif.

Banyak argumen yang menyatakan banyak korupsi yang tidak memandang jenis kelamin terutama kasus di pemerintah pusat, tetapi kenyataannya di daerah Yogyakarta kecenderungan perempuan untuk memberantas korupsi lebih tinggi daripada laki-laki. Hanya saja semua itu tidak cukup berpengaruh karena tidak adanya kesetaraan gender dalam hal akses, partisipasi, kontrol dan manfaat perempuan di lembaga legislatif. Kesetaraan gender inilah yang ternyata berpengaruh nyata dalam pemberantasan korupsi.

\section{Penutup}

Upaya pemberantasan korupsi diukur melalui indikator, pertama: aspek nilainilai yang meliputi integritas, profesional, mengutamakan kepentingan masyarakat dan negara, berwawasan kedepan. Kedua, yaitu aspek etika penyelengaraan negara yang meliputi perilaku individu, perlindungan harta milik negara, menghindari kepentingan pribadi. Ketiga, aspek pedoman perilaku yang meliputi kepatuhan terhadap peraturan, kerahasiaan informasi, pelaksanaan kewenangan, pengungkapan dan pelaporan penyimpangan. Keempat, aspek akuntabilitas meliputi penilaian tupoksi DPRD, pertanggungjawaban tugas, anti gratifikasi, dan responsibilitas. Hasil survey menyimpulkan bahwa perempuan lebih berperilaku mendukung upaya pemberantasan korupsi daripada laki-laki. Hal ini terlihat dari banyaknya indikator yang dimiliki perempuan dalam pemberantasan korupsi yang lebih unggul dibanding laki-laki. Sehingga pernyataan bahwa women less corrupt yang artinya perempuan memliki sifat korupsi yang lebih rendah dibanding lakilaki benar adanya dari hasil penelitian ini.

Hasil survey menunjukkan keadaan yang memprihatinkan dimana masih terjadi ketimpangan gender di DPRD Kota Yogyakarta. Dilihat dari akses maka perempuan dan laki-laki tidak berbeda. Sedangkan, nilai partisipasi perempuan jauh lebih tinggi dibanding dewan laki-laki. Namun, disayangkan kontrol 
perempuan sangat rendah dalam setiap kegiatan. Meskipun perempuan sudah banyak yang mengutarakan pendapatnya tetapi pendapat tersebut jarang dilaksanakan. Sedangkan dewan laki-laki lebih sering pendapatnya dilaksanakan. Ketimpangan ini masih membuktikan adanya dominasi laki-laki di DPRD Kota Yogyakarta. Hal ini dikarenakan kapasitas laki-laki jauh lebih besar dibanding perempuan dalam hal negosiasi atau pemahaman materi tupoksi ataupun aturan di legislatif. Dengan demikian, keunggulan perempuan dalam upaya pemberantasan korupsi tidak akan cukup berarti tanpa adanya kesetaraan gender.

Kesetaraan gender ternyata berpengaruh terhadap pemberantasan korupsi. Banyak argumen yang menyatakan banyak korupsi yang tidak memandang jenis kelamin terutama kasus di pemeritah pusat, tetapi kenyataannya di daerah Yogyakarta kecenderungan perempuan untuk memberantas korupsi lebih tinggi daripada laki-laki. Hanya saja semua itu lebih dipengaruhi oleh adanya kesetaraan gender di lembaga legislatif. Tanpa adanya kesetaraan gender maka upaya pemberantasan korupsi tidak akan lebih baik. Hal ini dibuktikan bahwa baik lakilaki dan perempuan telah memiliki keunggulan masing-masing dalam aspek nilainiai, aspek etika penyelenggaraan negara, aspek pedoman perlaku dan aspek akuntabilitas yang dapat saling melengkapi. Kecenderungan perempuan yang jauh lebih anti korupsi semakin berarti apabila adanya kesetaraan gender di legislatif. Peneliti menyimpulkan beberapa saran, yaitu: pertama, keunggulan anti korupsi pada perempuan perlu menjadi pendorong partisipasi perempuan masuk ke parleman. Kedua, kurangnya peran aktif perempuan yang lebih berkualitas di parlemen maka perlu peningkatan kapasitas dengan cara melakukan asistensi atau capacity building pada anggota dewan perempuan. Ketiga, adanya diskriminasi secara tidak langsung maka perlu membuat kebijakan pelaksanaan kegiatan yang lebih responsif gender dengan demikian akan terjadi optimalisasi kinerja dewan.

\section{Daftar pustaka}

Deni, Saiful. Korupsi Birokrasi, Naufan Pustaka,Yogyakarta, 2010.

Fakih Mansour, Analisis Gender Dan Transformasi, Pustaka Pelajar, Yogyakarta, 2007.

Gay,LR \& Diehl,PL Research Methods for Business and Management, Singapore, Simon \& Schuster (Asia) Pte Ltd, 1996.

Klitgaard, Robert, Membasmi Korupsi (diterjemahkan oleh Hermoyo), Yayasan Obor Indonesia, Jakarta, 1998. 
Komite Nasional Kebijakan Governance, Konsep Pedoman Good Public Governance, 2008.

Lubis, Mochtar dan James C. Scott, Bunga Rampai Korupsi, LP3ES, Jakarta, 1985.

Nugroho, Riant, Gender dan Strategi Pengarusutamaan di Indonesia, Pustaka Pelajar, Yogyakarta, 2008.

Ruslan, U. AM, Pendidikan Politik Ikhwanul Muslimin, Era Intermedia, Solo, 2000.

Slamet, Y. M.Sc., Metode Penelitian Sosial, Sebelas Maret University Press, 2006.

Alatas, Korupsi: Sifat, Sebab dan Fungsi, LP3ES, Jakarta, 1987.

Sri Wiyanti, dkk.. Kemandirian Perempuan dalam Pengambilan Keputusan pada Organisasi Publik. Pusat Penelitian dan Pengembangan Gender Lembaga Penelitian Universitas Sebelas Maret Surakarta, 2004.

Subono, Nur Iman. “Tokoh Politik Perempuan di Asia: Dinasti Politik atau Representasi Politik Perempuan?" dalam Catatan Perjuangan Politik Perempuan, Jurnal Perempuan, No. 63. Jakarta, Yayasan Jurnal Perempuan, 2009.

Sundari, Eva K, Advokasi Penganggaran Berbasis Kinerja Responsif Gender PATTIRO dan The Asia Foundation, Jakarta, 2006.

Nurhaeni, Ismi Dwi Astuti, Kebijakan Publik Pro Gender: UPT Penerbitan dan Percetakan UNS (UNS Press), Surakarta, 2009.

Umi Sumbullah M.Ag.. Gender dan Demokrasi, Averoes Press Bekerjasama dengan Program Sekolah Demokrasi PlaCID's, Malang, 2008.

David Dollar,et All. Are Women Really the "Fairer" Sex? Corruption and Women in Governance. October 1999. The World Bank, Policy Research Report On Gender and Development. Dalam http://citeseerx.ist.psu.edu/viewdoc/ download?doi=10.1.1.199.5857\&rep=rep1\&type=pdf, Tg1 21 Desember 2011

Farzana Nawaz. 2009. State of Research on Gender and Corruption. Nti Crruption Resource Centre. http:/ / www.transparency.org/polivy_research/surveysindices/gcb/2009. Diakses tanggal 21 Desember 2011

Fernanda Rivas. December 2008. An Experiment on Corruption and Gender. hal 8-10 dalam http://ideas.repec.org/p/gra/wpaper/08-10.html, diakses tanggal 21 Desember 2011.

Rawira Maulana. 31 Januari 2012. 12 Mantan Anggota DPRD dijebloskan Penjara. Tribunjogja. Dalam http://m.tribunnews.com/2012/01/31/12-mantananggota-dprd-yogyakarta-dijebloskan-penjara, diakses tanggal 5 Februari 2012

Detik. 02 Juni 2004. DPRD DIY diduga korupsi APBD 16 Milyar. Dalam (http:/ / infokorupsi.com/id/korupsi.php?ac=567\&l=dprd-diy-diduga-korupsiapbd-rp-16-miliar) diakses tanggal 5 Februari 2012. 